\title{
The Subjectivity Evolvement of the Chinese American Women's Writing
}

\author{
Qiufang Dong ${ }^{1, *}$
}

\author{
${ }^{1}$ College of Liberal Arts, Jinan University, Guangzhou, China
}

*Corresponding author. Email: 56236182@qq.com

\begin{abstract}
Judging from the English works of the representative Chinese American women writers since the second half of the 19th century, writers adopt different strategies to deal with racism, patriarchy and cultural differences, which directly affects the construction of female subjectivity in their works. Their writings present two characteristics in different historical periods: from rebellion to heterogeneous symbiosis, and from ethnic deviation to seeking roots. Chinese American women writers' writings have positive significance for contemporary Chinese American women to construct subjectivity. The writings also supplement history and help fight against hegemonism.
\end{abstract}

Keywords: Chinese American women writers, Significance of writing, Subjectivity.

\section{INTRODUCTION}

Subjectivity is "the condition of being a person and the processes by which we become a person; that is, how we are constituted as cultural sujects and how we experience ourselves."[1] In the postmodern context, deconstruction prevails and identity is no longer regarded as single or fixed. In Chinese American litetature, most writers take great efforts to portray how their characters pursue identity and construct subjectivity because of the complexity of their cultural background. With an overview of the historical background, this article focuses on the English works of the representative Chinese American women writers since the second half of the 19th century. Starting from the writers' portrayal of female characters, this article explores the evolvement of female subjectivity in their works. It also reveals the multiple hidden factors which affect their writing, and highlights the significance of their writing.

\section{THE EVOLVEMENT OF THE SUBJECTIVITY OF CHINESE AMERICAN WOMEN IN THE HISTORICAL CONTEXT}

In American history, WASP (White AngloSaxon Protestant) had always dominated the society, and they adopted racist policies towards ethnic minorities. Chinese Americans, along with other ethnic minorities, suffered from racism. But the government constantly adjusted racial policies according to the national interests in different historical periods, and the social status of Chinese Americans rose and fell accordingly. Compared with Chinese American men, the situation of Chinese American women was even worse. While suffering from racist discrimination, they had to deal with patriarchy within the community at the same time. With the two factors of race and gender, it is not easy for the Chinese American women to construct subjectivity. Thus the construction shows different characteristics in different historical periods. Linghu Ping once divided the immigration history of Chinese American women into three peirods: early immigration period from the middle of the 19th century to 1943; post-war period from 1943 to 1965; and contemporary immigration period from 1965 to the present. [2] This article will use this classification to explore how factors of race, gender and culture influence the construction of subjectivity of Chinese American women, and the discussion will focus on the contemporary era. 


\subsection{A Pioneer of Icebreaking Period (Mid- 19th Century-1943)}

From the mid-19th century to World War II, racial discrimination against Chinese in mainstream American society gradually formed and intensified. The California Gold Rush started in 1848 and soon attracted Chinese of the coastal rural areas of Guangdong Province to come to America to seek fortune. Most of them were engaged in manual labor in farms, mines, railways etc. Within a few years, the arrival of a large number of immigrants made white people worry that their employment opportunities would be taken away. At the same time, they were deeply concerned and annoyed that Chinese people were too attached to their own culture and tradition and refused to assimilate into American culture. Waves of excluding Chinese came one after another. In 1882, the United States Congress passed the Chinese Exclusion Law. After that it was legally accepted that Chinese held an inferior position in America and they could only engage in some of the dirty and ill-paid jobs and suffered from various prejudice and oppression.

During this period, the life of Chinese American women was as miserable as that of men. In 1875 , the Page Act promulgated by the United States effectively restricted the entry of Chinese coolies and Chinese women. [3] Even if Chinese women entered the United States, they either worked as prostitutes or worked hard in laundry business and restaurants. Due to their low social status and poor education, these women couldn't make their own voices. The mainstream culture portrayed Chinese women as two opposite and yet both negative images. One was the docile woman who knew nothing but obey men, and the other was the sexy prostitue. These two images constantly appeared in Hollywood films and other media. For example, the famous Chinese American actress Anna May Wong not only played as the dishwasher for many times, but acted as the sexy and yet evil mistress of white men.

Sui Sin Far (1865-1914) was a pioneer to write for Chinese in America. As a Eurasian with half Chinese descent, Sui Sin Far suffered from racial discrimination since her childhood. But she never believed that her mother was inferior to anyone as a Chinese. She took on writing to express her indignation towards the racial prejudice and defend for Chinese in America.

Sui Sin Far's writings were quite different from the autobiographical works written by other
Chinese of the same period, such as When I Was a Boy in China by Lee Yen Fu (1861-1938), America Through the Spectacles of an Oriental Diplomat by Wu Ting-fang (1842-1942), My Life in China and America by Yung Wing (1828-1912). These civilized Chinese were well educated and their lives in China and America were totally different from Chinese coolies. Although they were also troubled by racial discrimination, they never knew exactly how a Chinese laborer suffered in America. In their works, they tried to introduce the elegance of traditional Chinese culture to the American people, thus catering to those who appreciated the "Oriental exoticism". By doing so, they hoped to improve the image of Chinese and be understood and accepted by the mainstream society. Sui Sin Far differed from them in the aspect that she was more concerned with the life of ordinary Chinese Americans. She devoted herself to changing the image of Chinese, especially women. In Mrs. Spring Fragrance and its sequel, she portrayed an Americanized Chinese woman, Mrs. Spring Fragrance. Mrs. Spring Fragrance was always optimistic and cheerful. She had her own ideas and didn't blindly follow her husband. She differed from the traditional Chinese women who obeyed "three obediences and four virtues", and the docile or sexy image created by the white writers. Although she was not used to wearing Western costume when she first arrived in the United States, she adapted to American life earlier than her husband. She was ready to accept American values and actively integrated into American society. Mrs. Spring Fragrance was the ideal Chinese female representative of Sui Sin Far. She used this shining character to change the stereotype of the white society. In another story in Mrs. Spring Fragrance, she portrayed a pitiful Chinese woman. She poisoned her son not because she was vicious, but because she was perplexed by the strange and hostile foreign culture. In Sui Sin Far's writing, no matter what their circumstances are, those Chinese women are all real to life and never fall into stereotypes. It is fair to say that Sui Sin Far is a true pioneer of Chinese American literature.

\subsection{Model Ethnic Minorities Who Began to Speak Out (1943-1965)}

World War II was a turning point for Chinese Americans. The Pearl Harbor Incident made the United States unite with China to jointly fight against Japan. U.S. immigration policies and racial strategies changed accordingly. The hatred towards Chinese Americans eased. Because the war needed 
more laborers, Chinese women began to work outside Chinatown. With the improvement of the economic status, they were more actively engaged in politics and other social affairs. Their subjectivity consciousness was awakened, and they began to explore their ethnic and gender subjectivity, and made greater efforts to promote social status and integrate into the mainstream culture.

Most of the writers who were active in this period were the second generation of Chinese Americans. They were born to be American citizens and were quite different from their parents. The old generations were still attached to their motherland, while the second generation began to take America as home. When faced with racial discrimination, they would work harder to assimilate. Many writers showed a strong determination to melt into the mainstream culture.

Jade Snow Wong (1922-2006) was the most successful writer in this period and she had the greatest influence on later Chinese American women writers. Her autobiography, Fifth Chinese Daughter (1945), was an immediate hit after its publication. It not only sold well in America, but was translated into several other languages with the support of the US Department of State. The reason why it sold so well was that Jade Snow Wong's book came out at the right time. The government was willing to show friendship to Chinese Americans because of its alliance with China during World War II, and it also hoped to encourage other minorities to learn from the "model minorities" of Chinese by promoting Jade Snow Wong and her book. When faced with racial discrimination, Jade Snow Wong adopted a coping strategy of self-restraint. In the book, she admitted that racism did exist in the American society, but she proved through personal experience that she could still realize her American dream.

Fifth Chinese Daughter has an unprecedented positive impact on later Chinese American women writers. It was the first time that a Chinese American woman wrote how she realized her American dream. Jade Snow Wong tried to construct her subjectivity from three aspects. First, she used her ethnic background to gain mainstream attention. Second, she expressed her appreciation for American values. For example, she praised the white parents to respect the rights of the kids and treat them as equals. Third, she criticized patriarchy in her community severely. She was dissatisfied with the Chinese tradition of prioritizing males over females and strongly opposed to the idea of "Ignorance is women's virtue". She managed to go to college by doing part-times. After graduation, she started her own business. In the autobiography, Jade Snow Wong constructed a new image of Chinese American women. She has a huge influence on later Chinese American women. Maxine Hong Kingston once praised her as the "Mother of Chinese American Literature". [4]

\subsection{Advocates of Multiple Symbiosis (1965- Present)}

In 1965, the new Immigration Law promulgated by the United States Congress cancelled the low quota for Chinese immigrants. Chinese immigrants increased sharply, and the proportion of women also increased accordingly. While at this time, various political and cultural movements arose one after another, providing fertile ground for Chinese Americans to fight for better political and social position. The Civil Rights Movement initiated by African Americans forced the government to amend their racial policies. Subsequently, Asian Americans launched Asian American Movement. Women's Liberation Movement made Chinese American women to reflect on their situation. Afterwards, the rise of Multiculturalism opened up a new field for Chinese American women to explore their subjectivity. In these several decades, Maxine Hong Kingston, Amy Tan, Gish Jen, Fae Myenne $\mathrm{Ng}$, and Lisa See made outstanding contributions to the construction of subjectivity of Asian women through their writing.

Maxine Hong Kingston (1940- ) is truly a "woman warrior". In her novel, she attacked fiercely against patriarchy and racial discrimination that hindered the construction of female subjectivity. The Woman Warrior (1976) best expressed her search. In this novel, she employed sharp contrasts to emphasize the necessity of women's rebellion against the patriarchal tradition and racial discrimination. First of all, she portrayed two contrasting characters, Brave Orchid and Moon Orchid. Brave Orchid was the mother of the heroine. After the death of her two sons, she went to study as a midwife in Guangzhou. After graduation, she returned to her hometown and helped local women give birth. After coming to U.S., she and her husband worked together in the laundry to support the big family. While her sister, Moon Orchid, was accustomed to being a virtuous traditional wife who totally depended on her husband. She was afraid of changes and couldn't 
even handle the simplest laundry work. Abandoned by her husband, she suffered a mental breakdown and died in the hospital. Maxine Hong Kingston designed opposite endings for these two sisters to stress the need for women to fight against patriarchy and actively integrate into American society. Secondly, the author uses intertextuality to interweave American real life with ancient Chinese stories, creating the real "I" and the imaginary "I". The real "I" could not control her life. On one hand, she suffered from racism. Her parents' laundry workshop was pulled down by white people; the owner of the local store called her a "yellow ghost"; and she was fired simply because she reminded her boss not to eat in restaurants whose owner was a racist. On the other, in the Chinese community she was a girl of little importance. Even if girls got A in their homework, they wouldn't be considered better than boys. Maxine Hong Kingston felt frustrated with patriarchy in Chinese community and hoped to make some changes. As a result, she boldly rewrote the story of Hua Mulan and fabricated a heroine who was brave and resourceful in battles, and she powerfully refuted the Chinese traditional belief that girls were useless. It was also the imaginary heroine Hua Mulan that inspired the protagonist to break the silence both in Chinese and white communities, and grow into a woman with a strong desire to fight against patriarchy and racism.

Amy Tan (1952- ) is another great Chinese American woman writer after Maxine Hong Kingston. Multiculturalism clearly had a huge impact on her, which advocated diversities of cultures and insisted on an attitude of tolerance towards other cultures. Amy Tan is particularly fond of writing about mothers and daughters who often go through constant conflicts due to cultural differences but eventually reach reconciliation. In The Joy Luck Club (1989), the four mothers all had conflicts with their daughters. They worked hard to provide their daughters with the best education in spite of hardships, hoping that their daughters could follow their arrangements. However, the daughters went beyond the control of the mothers. They valued independence and freedom, and strongly resisted the mothers' manipulation. They regarded their mothers who ate Chinese food, wore cheongsams, and played mahjong at regular gatherings as oddballs in American society. On the surface, these conflicts seem insoluble. But in fact, mothers actually also adopted American values. When the mothers left China for America, they hoped to escape patriarchy and oppression of feudal society to seek a new life in the United States, so they wouldn't impose strict restrictions on their daughters. And their daughters finally realized the significance of their mothers to their growth. Ruth and her mother Lu Ling in The Bonesetter's Daughter (2001) experienced a similar evolvement from conflicts to understanding. The reason why the mother strictly disciplined her daughter was that she hoped she could help her daughter better adapt to the United States and become a strong and independent woman, which indicated that mothers themselves were actually trying to assimilate into American society. Gradually the daughters changed from rebellion to identification with their mothers. It shows that the second generations are ready to embrace Chinese culture. In the novels Amy Tan proves that even if the mothers and daughters conflict with each other, it is not insoluble because both generations have dual and hybrid cultural identities. There is a third space for communication and exchange.

Gish Jen (1955- ) believes that the immigration experience of each ethnic group belongs to the American national experience. She advocates a new "American attribute" that transcends races and cultures. She doesn't write much about history. She rejects exoticism and constantly challenges the stereotypes of Chinese American women. In Typical American (1991), Gish Jin uses irony to portray her female characters. Theresa, together with her younger brother Ralph and his wife, Helen, sneered at the "typical American" who valued money more than anything else. But they gradually became "typical American" themselves. Gish Jen doesn't fiercely attack the patriarchy in Chinese culture like Maxine Hong Kingston. She emphasizes that while assimilating into American society, it is not necessary for the Chinese to give up their cultural tradition. This apparent contradiction reflects Gish Jen's understanding of Americanness: Chinese Americans are Americans with unique ethnic characteristics, and they enrich Americanness with their cultural traditions. In Mona in the Promised Land (1996), Gish Jen goes further. The protagonist Mona converted to Judaism and wanted to be a Chinese Jew. Many characters in the novel changed their ethnic identities, and some even went through multiple conversions. Mona organized a summer camp, which was composed of white people, Jews, black people and Chinese Americans. In this camp, everyone was equal and could experience other cultures. Gish Jen fulfills her wish of racial integration by creating this summer camp. In her opinion, ethnic identity is 
not stable and single. It is affected by many factors and is in constant change.

Fae Myenne Ng (1956- ) lives in the same era with Gish Jen. Her masterpiece Bone (1993) focuses on a lower-class Chinese American family in San Francisco's Chinatown. The mother and the father were often at odds, while their three daughters adopted different strategies to cope with the traumatic history and cultural traditions. The second daughter, Ona, was unable to deal with the conflict between obeying her parents' wishes and love for her boyfriend. She chose to commit suicide to get out of the predicament. Her death symbolizes that if Chinese American women deal with cultural conflicts in an either-or manner, it will inevitably be a dead end. After the death of her sister and the separation of her parents, the youngest daughter, Nina, went to the east coast to work as a tour guide and stewardess, hoping to use distance and time to ease the trauma, but she failed. Of the three sisters, only the eldest sister, Leila, actually found solution. She was an ideal image of the second generation of Chinese Americans. She was willing to deal with the historical trauma and accepted her ethnic identity in a rational manner. After retrospection, Leila bravely shouldered her responsibility for her parents and for her community. She was determined to bridge the past and the present and embraced life as it was. Fae Myenne $\mathrm{Ng}$ is not obsessed with seeking female identities in her works like Amy Tan, Maxine Hong Kingston and Gish Jen. Instead, she hopes to reflect trauma by writing history and provide inspiration for later generation through her personal and family experiences.

Lisa See (1955- ) is only one-eighth of Chinese descent, but she is obsessed with telling the stories of Chinese. She has written 10 books on Chinese or Chinese Americans. Among them, Shanghai Girls (2010) and China Dolls (2015) focus on the experiences of Chinese American women before and after the Second World War. In Shanghai Girls, Lisa See writes the life experiences of two sisters of May and Pearl. To get away from Japanese invasion of China, they went to America for life. But America was actually not a heaven. They were first detained in Angel Island for several months and then lived a miserable life in Los Angels Chinatown and suffered from racism. In China Dolls, Lisa See explores ways for Chinese American women to recover from trauma by telling the story of three dancers in nightclubs. Even if Lisa See shows no trace of Chinese in her appearance, she is deeply influenced by Chinese culture, and regards herself as a member of Chinese American. She constantly travels between China and the United States, trying to incorporate her reflections on history and culture into her books and opens a window for the world to understand China.

\section{THE CHARACTERISTICS OF EVOLVEMENT OF SUBJECTIVITY}

The female subjectivity reflected in the abovementioned English works shows the following characteristics: from conflict and confrontation to heterogeneous symbiosis. Chinese American women have always been seeking for their own position in both the mainstream culture and in the Chinese American commmunity. In the era when Sui Sin Far lived, the Amercian society held strong prejudice towards Chinese. As a pioneer, Sui Sin Far's mission was to change the stereotypes. So her writing does not focus on criticizing patriarchy in Chinese American society, but to portray the actual life of Chinese Americans. The women in her works are not foot-binding ladies willing to be the shadow of their husbands. They have their own unique features and experiences. Jade Snow Wong happened to live in the ear in which the American government advocated "melting pot". Out of national interest, the United States strived to eliminate the original ethnic characteristics of ethnic minorities through education and cultural propaganda and hoped to transform the minorities into citizens with American values. Therefore, although Jade Snow Wong grew up in Chinatown, she advocates individualism and self-development. In order to integrate into the "melting pot", Jade Snow Wong worked hard to naturalize herself as an American. She boldly criticizes and abandons the Confucian collectivism and patriarchy, and successfully portrays herself as a representative of a model minority. Maxine Hong Kingston is deeply influenced by the African-American Civil Rights Movement and the Asian American Movement, and she is relatively radical. She absorbs nutrients from both Chinese and American culture, but she is also ready to attack anything which hinders her from constructing subjectivity. Amy Tan is more concerned with constructing a mixed subjectivity. The mothers and daughters in her novels have dual and hybrid cultural identities. The mother-daughter relationship changes from conflict to reconciliation. By the time Gish Jen lives, she has identified herself as an American writer. She is no longer satisfied with seeking a single and stable ethnic 
identity. Characters in her novels boldly challenge essentialism and strive for a flowing and open cultural identity. From an overall point of view, the subjectivity of Chinese American women changes from struggling to get out of the margin to dissolving the center, and from assimilation to symbiosis.

But at the same time, the Chinese American women writers show a trend from abandoning their ethnic culture to returning to it. Due to racist discrimination and cultural naturalization in the United States, Chinese American women in Jade Snow Wong, Maxine Hong Kingston and Amy Tan's books all rebel against Chinese culture in some degree. The heroines in Fifth Chinese Daughter and The Woman Warrior both attack patriarchal suppression; the four daughters in The Joy Luck Club resist the mothers who are portrayed as symbols of Chinese culture. However, with Multiculturalism, the contemporary Chinese American women show the tendency of returning to their cultural tradition and seeking roots. In The Joy Luck Club, Amy Tan is not satisfied with the reconciliation between the mother and the daughter in the United States. In the last section, Wu Jingmei returned to China to meet her lost sisters to fulfil her mother's long-cherished wish and begin to accept the fact that "part of me is Chinese". [5] With this ending, Amy Tan implicitly expresses her wish to reconnect with Chinese. Lisa See expresses her attachment to Chinese American community in a much more direct way. She clearly states in the preface of her family biography On Gold Mountain: "Though I don't physically look Chinese, like my grandmother, I am Chinese in my heart." [6] From the self-narration of these writers and the portrayal of the characters in their books, we can see that for Chinese American women, their ethnic background not only means responsibilities, but also a source of love and strength.

\section{CONCLUSION}

The writings of Chinese Americans originate from reality and yet go far beyond reality. They not only reflect the survival experience of Chinese Americans but express the writers' own pursuit of subjectivity. They write because they are unwilling "to accept fragmentation philosophically as a postmodern fact of life".[7] Writing is first a tool for those writers to construct subjectivity. In the forms of fiction and non-fiction, fabrication and reproduction, they boldly rebel against racism in the American society and patriarchy in Chinese
American community. In addition, their writings have a positive impact on Chinese American as a whole. Writers like Lisa See and Fae Myenne $\mathrm{Ng}$ are particularly good at writing Chinese American history. They record and supplement history with official and unofficial documents to combat forgetting and keep memory, so that the contemporary Chinese American can keep on gaining strength from the literary works.

\section{AUTHORS' CONTRIBUTIONS}

This paper is independently completed by Qiufang Dong.

\section{REFERENCES}

[1] Chris Barker. Cultural Studies: Theory and Practice. Thousand Oaks: Sage Publications, 2003, p.220.

[2] Linghu Ping. A History of Chinese American Women and Their Lives. Beijing: China Social Sciences Press, 1999, pp.17-18. (in Chinese)

[3] Kerry Abrams. "Polygamy, Prostitution, and the Federalization of Immigration Law", Columbia Law Review, Vol. 105, No. 3, 2005, p.641.

[4] Amy Ling. Between Worlds: Women Writers of Chinese Ancestry. New York: Pergamon, 1990, p.120.

[5] Amy Tan. Joy Luck Club. New York: Ivy Books, 1990, p.368.

[6] Lisa See. On Gold Mountain: The OneHundred-Year Odyssey of My ChineseAmerican Family. New York: St. Martin's Press, 2010, p.xx.

[7] Judith Oster. Crossing Cultures: Creating Identity in Chinese and Jewish American Literature. Coumbia: University of Missouri Press, 2003, p.57. 